\title{
THE EFFECT OF HEALTH EDUCATION BY THE ROLE PLAY METHOD ON KNOWLEDGE LEVEL ABOUT PREVENTION OF SEXUAL VIOLENCE IN SCHOOL AGES
}

\author{
Meilinda Ulfah Adha Suhenda ${ }^{1}$, Tetti Solehati ${ }^{2 *}$, Ai Mardhiyah ${ }^{3}$ \\ ${ }^{1,2,3}$ Faculty of Nursing, Universitas Padjadjaran \\ Corresponding: tetti.solehati@unpad.ac.id
}

\begin{abstract}
Cases of child sexual violence (KSA) in Bandung Regency continue to increase, and cause physical, psychological, growth, development and traits in the future. KSA prevention education is needed as primary prevention to increase children's knowledge in order to protect themselves. This study aimed to analyze the effect of education through the role play method on the level of knowledge regarding the prevention of school-age KSA in Solokan Garut Elementary School, Bandung Regency. This type of research was Pre-Experimental with One group pre and posttest design. Sample selection used purposive sampling techniques. The study involved 47 respondents from grade 1 and 2 students at Solokan Garut Elementary School in Bandung Regency. The treatment in the form of education to prevent KSA at school age uses the "TANGKIS" jargon with the role play method. The instrument used a modification of the "TANGKIS" material questionnaire and early age education journal that has done face validity and instrument testing with valid and reliable results 0.87 . Data were analyzed using univariate analysis of frequency distribution and percentage, and bivariate analysis of the Wilcoxon test. The results showed an increase in children's knowledge when the Pre-test was 34 children in good category $(72.3 \%)$ and increased when the Posttest as many as 38 children in the good category (80.9\%). In bivariate analysis, there was a p-value of 0.016 . The conclusion of this study is that there are significant differences in the level of knowledge of school-age children before and after being given education through role play regarding prevention of KSA in Solokan Garut Elementary School, Bandung Regency. The advice of this study is to apply this method regularly and develop other educational methods that are suitable and effective for adolescents.
\end{abstract}

Keywords: Education, Knowledge, Prevention of sexual violence, School-age children.

\section{INTRODUCTION}

Currently, the condition of Sexual Violence in Children (KSA) in Indonesia has entered the status of "Emergency Sexual Violence Against Children". This happens because the incidence of sexual violence against children continues to increase, the area of acts of sexual violence is increasingly widespread, and acts of sexual violence are increasingly complex (Erlinda, 2014). Including in Bandung Regency, this district has the highest number of KSA cases in West Java (Regional Development Planning Agency (BAPPEDA) West Java, 2016). The highest number of KSA in Bandung Regency is found in Solokan Jeruk District. The types of cases of sexual violence are cases of molestation. Cases of sexual abuse occur in children aged 2.5 years to 9 years. There was also one rape case that occurred in 15 -year-old children in Solokan Jeruk District (P2TP2A Bandung Regency, 2016).

There are several factors that increase the possibility of KSA, including the level of knowledge, poor parenting skills, low education level, alcohol and narcotics abuse, the 
presence of domestic violence, previous criminal records, mental illness, unemployment and poverty, parental work hours. length, stress, social isolation (eg from minority groups), lack of supervision of household activities, and indifference among household members (Maharani et al., 2015).

KSA has a short-term and long-term impact on victims (UNICEF, 2016). Short-term effects include: physical effects (abrasions in the vaginal or anal area, itching in the genitals, difficulty sitting or walking, broken bones, burning, and infection) and psychological effects (traumatic, fear, anxiety, difficulty eating, disorders sleep, insecure, easy to hate, indifferent, vindictive, easy to take shortcuts, easy to give up, sensitive and irritable, suddenly sticky with his parents and his attitude becomes more childish). While the long-term impacts include: the impact on growth (growth of the child's body becomes hampered, malnutrition, infection, and disability), the impact on children's development (emotionally disturbed, difficult to distinguish between good and bad things, low academic achievement, not creative and not productive), and the nature of children in the future (depressive, aggressive, psychopathic, anarchist and criminal) (Maharani et al., 2015). In addition to the impact experienced by victims of KSA also felt by families whose children experience sexual violence, namely psychosocial problems in the form of family dysfunction and post-traumatic stress which can create a burden on the family and cause families to experience psychological crises (Novianty, 2015)

One way to overcome the impact of KSA is prevention. Based on the results of Paramastri's research, Supriyati, \& Priyanto (2010), it was found that early prevention programs for KSA are very necessary and must be done immediately. Primary prevention is an effective way to overcome the effects of KSA (Cecen-Erogul \& Harisci, 2013). Primary prevention efforts take the form of age-appropriate education and protection services so as to increase knowledge. Knowledge possessed by children will become a means of protecting themselves from the harmful potential in the surrounding environment.

Many victims of KSA cases occur in school-age children (33\%) and the lowest in pre-school age (0-5 years) (7.7\%) (Indonesian Pediatrician Association (IDAI), 2014). The period of school-age children is divided into three age stages, namely the initial stage 6-7 years, the mid-stage 7-9 years and pre-adolescents 10-12 years (DeLaune \& Ladner, 2002; Potter \& Perry, 2005). Given the importance of awareness of sex education in children of an earlier 
age (Justicia, 2006), the period of early school age children is a priority for education regarding the prevention of KSA.

Effective sexual education requires appropriate education methods and media. The role play method in children, they do not feel bored in learning activities (Astuti, 2012). According to Cecen-Erogul \& Harisci (2013) besides using passive approach methods such as lectures, videos, and images, active approaches such as role play are also important to use. Based on the results of Systematic Reviews conducted by Walsh, et al. (2015), 24 research studies with a total of 5802 school-age children in the United States, Canada, China, Germany, Spain, Taiwan and Turkey were reported, reported that training methods, practices and role play is the most widely used. The material taught includes personal safety regulations from situations of sexual violence, body ownership, personal parts of the body, differentiating touch types and types of secrets, and to whom to report incidents (Walsh et al, 2015). To make it easier for children to remember the material, researchers used the "TANGKIS" jargon designed by Maharani (2015) because the content of the material was similar to what was expressed by Walsh. "TANGKIS" stands for "Your body is yours", "There is a secret behind your clothes", "You can't do it or not", "The danger of being vigilant", "If the opponent is forced", Remember all the secrets are good " to people who are believed " According to the results of the preliminary study on January 20, 2017, information and recommendations were obtained from P2TP2A Bandung District, Bandung District Solokan Jeruk Health Center and Elementary School Office Technical Implementation Unit (UPTD SD) in Solokan Jeruk District, Bandung Regency, that one type of sexual violence case, sexual abuse occurred in Solokan Jeruk Elementary School, in August 2016, the victim was in grade 2 elementary school. Students of Solokan Jeruk has never received counseling on preventing sexual violence in children. The local health center also said that it had never provided counseling to elementary school children in the Solokan Jeruk area, because so far it had provided information on preventing sexual violence only for teenagers, namely around Solokan Jeruk Middle School. Seeing this information, providing information relating to sexual violence will increase the knowledge of elementary school children as an effort to prevent sexual violence in children. Based on the explanation, the researcher was interested in conducting research on the effect of education through the role play method on the level of knowledge about the prevention of sexual violence in school-age children. 


\section{METHODS}

The research method was Pre-Experimental research with the design of One group pre and post-test design. This study had 2 variables, which are the independent variable is education regarding the prevention of KSA and the dependent variable is the knowledge of school-age children regarding the prevention of KSA. This study involved 47 respondents of grade 1 and 2 students at Solokan Jeruk Elementary School in Bandung Regency who was selected using Purposive Sampling techniques with inclusion criteria, namely students who had never received KSA prevention education and were able to read and write. The instrument used a knowledge questionnaire for pre-test and post-test questions regarding prevention of KSA designed by April in 2016 and has been modified from 17 questions to 22 questions because it is adapted to "TANGKIS" educational material with 2 choices A and B. The instrument is already validity was tested using Pearson Product Moment and reliability testing using the formula Kuder Richardson (KR-20) by Aprilaz. The treatment in the form of prevention of sexual violence education in school-age children is given using the "TANGKIS" jargon with the role play method that is supported by the slide and video media. Data analysis used univariate analysis and bivariate analysis. Univariate analysis was carried out with frequency distribution and percentage aimed at looking at the level of children's knowledge using 3 categories namely Good (76-100\%), Enough (56-75\%), and Less $(\leq 55 \%)$. The bivariate analysis used the Wilcoxon test because data distribution is not normal. Wilcoxon test aimed to see differences in the level of knowledge between before and after being given education through the role play method in school-age children.

\section{RESULT}

Table 1. Results of Wilcoxon Test Analysis of Pre-Test and Post-Test Values of SchoolAge Knowledge $(n=47)$

\begin{tabular}{ccccccc}
\hline Level of & \multicolumn{2}{c}{ Pre-test } & \multicolumn{2}{c}{ Post-test } & Z & $p$ \\
\cline { 2 - 5 } Knowledge & F & $(\boldsymbol{\%})$ & F & $(\%)$ & & \\
\hline Good & 34 & 72.3 & 38 & 80.9 & - & .016 \\
Moderate & 11 & 23.4 & 7 & 14.9 & 2.398 & \\
Poor & 2 & 4.3 & 2 & 4.3 & &
\end{tabular}


Table 1 describes the level of knowledge of school-age children regarding the prevention of child sexual violence, the results of the Pre-test showed that most of the knowledge was good for 34 children (72.3\%). The level of knowledge of school-age children when the Post-test shows most have good knowledge $(n=38,80.9 \%)$. From these results, it can be concluded that there is an increase in the level of knowledge of school-age children in SD Solokan Garut. The level of knowledge difference Pre-test and Post-test obtained a value of P 0.016 which means that the p-value is below $0.05(\mathrm{p}<0.05)$, thus it can be concluded that there is a significant difference in the level of knowledge before pre-test and after education (Post-test).

Table 2. The highest and lowest answer average at Pre-Test and Post-Test based on Question Themes $(n=47)$

\begin{tabular}{|c|c|c|c|}
\hline \multicolumn{2}{|r|}{ The question themes } & \multicolumn{2}{|c|}{ Mean } \\
\hline & & Pre-test & $\begin{array}{r}\text { Post- } \\
\text { test }\end{array}$ \\
\hline $\mathbf{T}$ & "My body is mines" & 0.81 & 0.83 \\
\hline $\mathbf{A}$ & $\begin{array}{l}\text { There is a secret } \\
\text { behind your clothes }\end{array}$ & 0.93 & 0.95 \\
\hline $\mathbf{N}$ & $\begin{array}{l}\text { No, You are not } \\
\text { allowed }\end{array}$ & 0.94 & 0.96 \\
\hline $\mathbf{G}$ & A danger alert & 0.84 & 0.95 \\
\hline $\mathbf{K}$ & If forced, opponent & 0.86 & 0.88 \\
\hline $\mathbf{I}$ & $\begin{array}{l}\text { Remember, not all } \\
\text { secrets are good }\end{array}$ & 0.61 & 0.67 \\
\hline $\mathbf{S}$ & Always tell parents & 0.62 & 0.72 \\
\hline
\end{tabular}

Table 2 found that the theme of the Pre-Test and Post-Test questions with the highest average answers was found in the theme of question N, which is about "No You are not allowed ". The average Pre-test was 0.94 and increased after being given education (Post-test) to 0.96. While the theme of the questions Pre-test and Post-test with the lowest average answer on the theme of question I is about "Remember, not all secrets are good". The average pre-test was 0.61 and increased after being given education (Post-test) to 0.67 . 


\section{DISCUSSION}

According to the results of this study, the description of the level of knowledge of the respondents at the time of the Pre-test and Post-test mostly increased and included in the good category. The results of this study are also similar to the research conducted by Siska, 2011 where children who were given the role play method had higher communication skills compared to children who did not get the role play method. Based on the research of Jatmikowati (2015) it was proven that early childhood sex education materials were very effective when carried out through role play. This shows that the education provided uses the role play method that is good and easily understood by school-age children, especially in the early stages of Solokan Garut Elementary School, Bandung Regency.

The increasing level of knowledge of school-age children occurs because of the growth and development of the child itself. Erikson's development theory (1963) states that school-age children are included Industrial vs Inferiority. These stages are activities that are being carried out by school-age children, one of which is the greater interest in knowledge. From the theory, it was concluded that the development of school-age children who were interested in knowledge would affect the level of knowledge of school-age children.

The results of the pre-test obtained that the level of knowledge of school-age children in SD Solokan Garut was a good category. Researchers assume that, even though children have never received education regarding prevention of sexual violence from educators such as teachers and health workers, knowledge can also be obtained from other factors so that the level of knowledge of school-age children is said to be good. Information factor is one of the factors that can affect children's knowledge, this factor is obtained from anywhere, one of which is mass media whose network is wide and easily accessible, this can affect children's cognitive and affective functions (Mubarak, 2007). In addition to information factors, environmental factors can also affect one's knowledge. A family environment is a place for respondents to be able to receive information about knowledge about the prevention of sexual violence from parents (Notoadmojo, 2010). Factors that aggravate the case of KSA in the Solokan Garut Elementary School in Bandung Regency have not been comprehensively studied, such as the factor of parent and teacher knowledge, has there been any crime in the 
environment and the respondent's home environment, economic status in the environment, stressors and others.

The results showed that there were 11 children who experienced a decline in knowledge. The decrease in knowledge occurs due to factors including environmental factors, material delivered, teaching language used, media used and children's intelligence (Handayani, Emilia, \& Wahyuni, 2009). This is also due to the less effective role play education strategy. According to McSharry and Jones (2000), although role play, it is recommended to start by playing a short role and do it gradually, and to play a longer role both do after the teacher and students have some initial experience and confidence. Role play activities also do not have to be given immediately before or after the test (pre-test and post-test), because the test can cause stress for students and the negative effects of the effectiveness of this activity (Case \& Cheek-O’Donnell, 2015).

Pre-Test and Post-Test with the highest average answer, namely on the theme $\mathrm{N}$ question about "You can't, yes you can't". This is consistent with the research conducted by Blakey (2015), that in class 1 when the Pre-test as much as $90 \%$ of children get the highest average value associated with the child's courage to say no, go away and tell the trusted person if there is someone unknown ones want to touch parts that cannot be touched. This is in line with a study carried out by UNESCO and the Independent Youth Alliance in 2014, which clarified that comprehensive sexuality education provides life skills education for children and adolescents about the ability to refuse and protect themselves from forms of violence. According to Fonner (2014), a positive long-term impact was also obtained by children, which encouraged children to have the courage to refuse sexual relations, compared to those who did not get sexuality education. Based on longitudinal research by FKM UI Together with Rutgers WPF Indonesia during 2011 and 2013 showed that children who get sexuality education will be able to prevent violence. This shows that sexuality education is a strong provision for children to refuse sexual violence.

While the theme of the questions Pre-test and Post-test with the lowest average answer is on the theme of question I which is about "Remember, not all secrets are good". this is in accordance with the research conducted by Blakey (2015), that the pre-test results in class 2 elementary school showed the lowest average value of $60 \%$ of children feeling confused to talk, be quiet, or refuse when someone is doing sexual harassment. The results of this study also show the difference in the average value of respondents' knowledge between before (Pretest) and after (Post-test) given intervention through the role play method is $-2,398$. Negative 
values indicate that the average value before the intervention was smaller than the average value after the intervention so that the average value of respondents' knowledge increased after being given an intervention with the role play method.

Based on the results of bivariate analysis shows that education on prevention of sexual violence in children with the role play method has an influence on the level of knowledge of school-age children, especially the initial stages, namely class I and II in elementary school. These students have a relatively younger school age between the ages of 7 and 8 years. Seeing the characteristics of school-age children according to Wong et al (2009), namely the curiosity of early school-age children is very large who want to know why an object exists, why the object is used, how it works, what the purpose of use is, so starting the role play activities, it was seen that children became enthusiastic to be able to do role play in front of the class with their friends.

Role play is carried out by students in accordance with a predetermined role. When students do role play, they look very confident, and happy. This is in accordance with the findings of Madyawati (2016), that the role play method builds children's confidence, children feel the sensation of being the characters of their roles so that children's confidence increases, and it is fun to play with friends using various toys, and communicate while playing. According to Kardoyo \& Hayuningtyas (2009), the role play method provides a pleasant atmosphere, children are actively involved in learning so that they are more enthusiastic in attending lessons and better understanding the subject matter, resulting in increased learning values.

It has been identified that there are some shortcomings of role play methods such as there is no experience in carrying out role play. The experience of children in performing role play influences the smooth running of activities, some children are not clear how to do it, so when given education using role play there are some children who are passive because they feel embarrassed and afraid to make mistakes when doing role play. This is in accordance with Smilansky in Azizah (2013), Children who have little role-playing experience seem to have difficulty in arranging their activities and conversations. The relationship between methods and educational media with the brain's absorption of learning shows by playing drama, simulating the actual situation and practicing it directly, the brain absorbs $90 \%$ of what we say and do (Oktawardani, 2008). From the information above, the role play method is the 
most influential method of information absorption, namely the brain absorbs $90 \%$ of what we have said and done.

Nursing implications include nurses as advocates must be aware of children's rights to need security and comfort so that children are not afraid and brave to tell things about sexual violence to people who are trusted by children so that children can be open to sharing their experiences. In addition to acting as a child advocate, Hardanti's research (2013) also said that nurses also play a role as family advocates, namely by exploring family goals and needs, planning the best actions to overcome problems, providing information choices that are relevant to children's interests, and providing health education for children and families.

\section{CONCLUSION}

It can be concluded that the education provided by the Role Play method on prevention of KSA is easily understood by school-age children, especially in the early stages, namely class I and class II in elementary school. Education through the role play method is proven to provide an increase in knowledge of school-age children. The results of the bivariate analysis can also be concluded that there are significant differences at the level of knowledge before and after role play. This research is expected to be used as the material for consideration to make a regular education program for early school-age children regarding prevention of sexual violence by using the role play method as a method of learning children. The next researcher was a re-evaluation of the level of knowledge of children after being educated for a long time (for example, 2 weeks after being given education) and researchers could explore other educational methods that could effectively influence the increase in knowledge.

\section{REFERENCES}

Aprilaz, Istiqomah. (2016). Perbandungan Efektivitas Antara Metode Video Dan Cerita Boneka Dalam Pendidikan Seksual Terhadap Pengetahuan Anak Presekolah Tentang Personal Safety Skill (Skripsi). Universitas Islam Negeri Syarif Hidayatullah, Jakarta.

Astuti, Peny Puji. (2012). Efektifitas Metode Bermain Peran (Role play) Untuk Meningkatkan Keterampilan Komunikasi Pada Anak. Jurnal Fakultas Psikologi, 2(1).

Azizah, Nur. (2013). Tingkat Keterampilan Berbicara Ditinjau dari Metode Bermain Peran pada Anak Usia 5-6 Tahun (Skripsi). Universitas Negeri Semarang, Semarang. Retrieved from website: http://lib.unnes.ac.id/18753/1/16 01409035.pdf.

BAPPEDA JABAR. (2016). Jabar Lawan Kekerasan Seksual terhadap Anak. Retrieved from website:

http://bappeda.jabarprov.go.id/jabar-lawan-kekerasan-seksual-terhadap-anak/. 
Blakey, J. M., \& Thigpen, J. W. (2015). Play it safe®: A school-based childhood physical and sexual abuse prevention program. Journal of Adolescent and Family Health, 7(1), A, B, 1-27. Retrieved from website:

https://search.proquest.com/docview/1831352797?accountid=48290.

Case, G. \& Cheek-O'Donnell, S. (2015). A Better Way for Role Play. Retrieved from website: https://medicine.utah.edu/faculty-dev/programs/academy-med-

education/docs/symposium_2015_powerpoints/ws-a-better-way-for-role-play.pdf.

Çeçen-Eroğul, A. R., \& Hasirci, Ö. K. (2013). The effectiveness of psycho-educational school-based child sexual abuse prevention training program on turkish elementary students. Educational Sciences: Theory \& Practice, 13(2), 725-729.

Delaune \& Ladner. (2002). Fundamental of Nursing Standarts \& Practice Second Edition. USA: Delmar.

Erlinda. (2016). Upaya Peningkatan Perlindungan Anak dari Bahaya Kekerasan, Pelecehan dan Eksploitasi. Komisioner Komite Perlindungan Anak Indonesia, Jogjakarta.

Hardanti, H. A., Nurhidayah, I., \& Fitri, S. Y. R. F. (2013). Faktor-faktor yang Melatarbelakangi Perilaku Adiksi Game Online pada Anak Usia Sekolah. Jurnal Keperawatan Padjadajaran, 1(3), 166-175.

IDAI. (2014). Mengajari Kewaspadaan Kekerasan Seksual Pada Anak. Retrieved from website: http://www.idai.or.id/public-articles.

Jatmikowati, Angin, E. (2015). A Model And Material of Sex Education For Early- Aged- Children. Cakrawala Pendidikan, 132(3), 434-448.

Justicia, R. (2016). Program Underwear Rules Untuk Mencegah Kekerasan Seksual Pada Anak Usia Dini. Jurnal Pendidikan Usia Dini, 9(2). 217-232.

Kardoyo \& Hayuningtyas. (2009). Role Playing dalam PS-Ekonomi. Jurnal Pendidikan Ekonomi, 4(2). 141-160.

Madyawati, Lilis. (2016). Strategi Pengembangan Bahasa Pada Anak. Jakarta: Prenada Media Group.

Maharani, F. D., Setia, F., Ranadireksa, A., Raharjo, F. D., Simatupang, D. F., Susilowati, A., \& Rosmiati. (2015). Anak adalah Anugerah: STOP Kekerasan terhadap Anak. Jakarta: Dirjen Informasi dan Komunikasi.

McSharry, Gabrielle \& Jones Sam. (2000). Role-play in Science Teaching and Learning. School Science Review, 82(298), 73-82. Retrived from website: http://www.sycd.co.uk/who_am_i/pdf/excite/sept_2000_73_82.pdf.

Mubarak, Wahit Iqbal, dkk. (2007). Promosi Kesehatan Sebuah Pengantar Proses Belajar Mengajar dalam Pendidikan. Yogyakarta: Graha Ilmu.

Novianty, L., Suryani., \& Sriati, A. (2015). Analisis Dukungan Psikososial yang dibutuhkan Keluarga dengan Anak yang mengalami Kekerasan Seksual. Jurnal Keperawatan Padjadajaran, 3(3), 139149.

Nursalam. (2008). Konsep dam Penerapan Metodologi Penelitian Ilmu Keperawatan. Pedoman Skripsi, Tesis, dan Instrumen. Edisi 2. Jakarta: Salemba Medika. 
Meilinda Ulfah Adha Suhenda: The Effect of Health Education By The Role Play Method

Paramastri, I., Supriyati, \& Priyanto, M. (2010). Early prevention toward sexual abuse on children. Jurnal Psikologi. 37. No 1(1), 1-12.

Potter dan Perry. (2005). Fundamental keperawatan; konsep, proses, dan praktik. Jakarta: EGC.

P2TP2A Kabupaten Bandung. (2016). Kompilasi Data Kasus P2TP2A - SAPA Institut - PDAK Yayasan JARI Periode Januari - September 2016.

Siska, Yulia. (2011). Penerapan Metode Bermain Peran (Role Playing) Dalam Meningkatkan Keterampilan Sosial dan Keterampilan Berbicara Anak Usia Dini (Jurnal). Universitas Pendidikan Indonesia. Bandung: Edisi khusus No. 2. 31-37.

Walsh, K., Zwi, K., Woolfenden, S, \& Shlonsky, A. (2015). School-based education programmes for the prevention of child sexual abuse. Cochrane Database of Systematic Reviews, Issue 4. Art. DOI: 10.1002/14651858.CD004380.pub3.

Wong, D.L, Hockenberry, M, et al. (2009). Buku Ajar Keperawatan Pediatrik. Alih bahasa, Monica Ester; (6th. ed). Volume 2. Jakarta: EGC. 